\title{
ТОЛКОВИЩЕ
}

\author{
Е.Т. Лобачевская, Р. Хайрутдинов
}

\section{ИНТЕРВЬЮ РУСЛАНА ХАЙРУТДИНОВА С ВДОВОЙ ВАЛЕРИЯ АЛЕКСАНДРОВИЧА ЗАЛОТУХИ ЕЛЕНОЙ ТЕОДОРОВНОЙ ЛОБАЧЕВСКОЙ}

\begin{abstract}
Аннотация. Материал рассказывает о творчестве известного российского литератора и кинодраматурга Валерия Александровича Залотухи (1954-2015). В своём творчестве В.А. Залотуха поднимал острые социальные вопросы. Наш корреспондент встретился с Еленой Теодоровной Лобачевской, чтобы обсудить творчество известного писателя и отметить неоспоримые достижения его произведений, в том числе романа "Свечка» и сценария к картине «Мусульманин». Фильм «Мусульманин» сохранил свою актуальность не только в момент экранизации произведения, но и в последующие годы. Острота психологического конфликта вызвана тем, что российский солдат, попавший в плен к мусульманам, вернулся в родную деревню. Парадокс рассказанной истории заключается в том, что, столкнувшись с этой религией, герой стал иначе смотреть на жизнь. Воспринятые им ценности поразительно противоречили деревенским нравам с пьянством, тупостью и жестокостью поведения.

В беседе использовались элементы такого жанра, как интервью. В разговоре нашли отражение основные идеи экзистенциальной философии, в частности, работы Виктора Франкла.

Впервые в отечественной литературе излагается история написания романа "Свечка». Обсуждается зарождение сценария к картине «Мусульманин», идея которого возникла на документальной основе. В.А. Залотуха увидел в телевизионных новостях возвращение солдата, который стал мусульманином, к матери. Изложена также история появления документального фильма "Ангел Русской церкви против Отца всех народов». Идея фильма связана со словами из пушкинского «Борис Годунова». Юродивый на просьбу царя молиться за него, отвечает: "Нельзя молиться за царя ирода». Оченивается также художественный фильм «Попы». Кроме того в беседе затронуты темы, которые волновали В.А. Залотуху, но, к сожалению, они не были реализованы.
\end{abstract}

Ключевые слова: литература, политика, кинематограф, творчество, мусульманство, власть, идеология, В. Франкл, учение о смысле, характеры.

Abstract. The article tells us about the creative life of a famous Russian author and scriptwriter Valery Zalotukha (19542015). In his creative writing Valery Zalotukha raised nettlesome social issues. Our newsperson had a meeting with Elena Lobachevskaya in order to discuss the creative life of a famous writer and outline unquestionable achievements of his writings including his novel 'The Candle' and his script for the film 'A Moslem'. 'A Moslem' was an important film at the time of its creation and it still remains important today. The psychological conflict in the film was caused by the fact that a Russian soldier who had been captured by Muslims came back to his home village. The values he adopted were startingly contradictory to the village traditions of excessive drinking and blunt and cruel behavior. In his conversation Khayrutinov used such elements of the genre as an interview. The main ideas of existential philosophy, in particular, Viktor Frankl's views were touched upon by the interlocutors. For the first time in the Russian academic sources the history of writing the novel 'The Candle' is presented. The interlocutors also discussed how the idea of the script 'A Moslem' was created which had a documentary basis. Valery Zolotukha saw the TV news telling about the soldier who became a Muslim coming back home to his mother. The interlocutors also discussed the origin of the documentary film 'The Angel of the Russian Church Versus the Father of All Nations'. The idea of the film is closely connected with the words from Alexander Pushkin's 'Boris Godunov' when the tzar asks a fool for Christ to pray for him and the fool answers 'I can't pray for Herod'. The interlocutors also gave their evaluation of the movie 'The Priests'. Moreover, they touched upon the topics Valery Zalotukha was concerned about but unfortunately had no time to reveal.

Key words: characters, theory of the life meaning, Viktor Frankl, ideology, power, Islam, creativity, cinematography, politics, literature. 
- Начинается наше интервью, естественно, приветствием.

- Начинается приветствием? Роман-то «Свечка» дочитали?

- Да, естественно.

- Да? Молодец.

- Я дочитал его, между прочим, ещё до Нового Года. Мы с Вами увиделись, и через четыре дня я дочитал его. Я просто сел и сказал, что пока не дочитаю, уже не успокоюсь.

- Мне такое письмо пришло трогательное от мамы замечательной художницы Дарьи Черновой. Она прочитала роман и такое письмо написала. У меня самые хорошие письма от священников, и вообще, конечно, от православных людей. Она очень хороший православный человек. Дарья написала, что не представляет, что прочесть после, что не знает, как будет жить без Золоторотова, сейчас я попробую открыть её письмо.

- Нет, на самом деле тяжело. Вы, конечно, с супругом сделали колоссальную работу и после неё тяжело, тяжело. Ты дочитал и у тебя два варианта выбора, я нашёл второй выбор после «Войны и Мира», что можно почитать после 3олоторотова.

- Что?

- Всё что связано - Ветхий Завет, Новый Завет, Библия, пожалуйста.

- $\quad$ Ну да-да-да-да-да. Это проблема - что... У меня была очень большая проблема. Потому что я после Валериной смерти вообще практически не могла читать. Только если я бралась так за рассказы Фицджеральда, что-нибудь такое, рассказы. А летом, мне надо было вычитывать. В первом издании было очень много опечаток, ляпов. И нам надо было выпустить с маркой, в шортлисте «Большая Книга», уже чистую. Потому что в июне всё раскупили и выпускался второй тираж. И надо было выпустить уже книжку чистую, без ляпов. Там есть какие-то ляпы дурацкие совершенно. И я села и две недели, не разгибаясь, просыпалась в семь утра и вычитывала все эти ляпы.

- В семь утра? Вы и в семь утра?

- Почему? - Ночью я не могла, а мне надо было подловить какой-то момент, когда я смогу читать отстранённо. В семь утра, где-то до одиннадцати я вычитывала, потом досыпала. И вот после этого у меня возникла большая проблема чтения. Я это сдала и накупила себе книжек, очень хороших романов и книжек, которые я хотела прочесть. Начинаю, пару глав читаю, отбрасываю, начинаю... что-то не шло. Единственное что я смогла читать после этого - Виктора
Франкла. Это такой психолог, венская школа психологии. Научные лекции по психологии Виктора Франкла. Воля к смыслу - вот это то, что я читаю сейчас как «Три Мушкетера». Научные лекции, которые, по-моему, в целом из американского университета. После «Свечки» я читаю Виктора Франкла.

- Это можно как рекомендацию расценивать?

- Нет, это гениальный философ, точнее - это гениальный психолог, не философ, это человек, которой относится к венской школе психологии, значит... Фрейд, Адлер, по-моему, и Франкл. То есть, Фрейд - стремление к удовольствию, Адлер - стремление к власти, а у Франкла воля к смыслу. С точки зрения Франкла, лечение любых неврозов, любых депрессий - это помощь человеку обрести смысл, найти смысл существования. Если психоанализ Фрейда основан на поисках в детстве каких-то сексуальных травм и комплексов, Адлера - анализ властолюбия. А у Франкла психоанализ основан на том, что человек в какой-то момент потерял смысл и от этого все неврозы, депрессии.

- В какой-то мере это роман «Свечка»...

- Вот-вот. Поэтому я читаю с увлечением Франкла. Это мой любимый психолог сейчас и философ. Мне это интереснее чем сюжетные, художественные какие-то книжки, пока я такой нашла выход и эта тоненькая книжечка у меня лежит, я её дочитала уже. Или какие-то дневники, ну, дневники это так - развлечение.

- Ну, дневники - это больше не чтиво, это больше как... не знаю, я сравниваю это с телесериалами. Тебя захватывает бытийный сюжет.

- Дневники людей своего детства, дневник Паолы Волковой, Вдовы Сидора, такой огромный. Потому что, там описаны жизни людей из моего детства. Это как такое развлечение, сродни сплетням. Сплетни о ярких людях.

- Ну и полная картинка плюс.

- Да. Вот. А вот Виктор Франкл это действительно... Мы с Валерой тоже его любили. Мы читали «Психолог в концлагере»... Валерка любил его.

- А не Франкл написал «Скажи жизни “да"»?

- Да, Франкл.

- Я его читал.

- Да? Правда чудесно? А вот эта «Воля к смыслу» они лекциями. Просто... они прямо вот поддерживают. Они поддерживают, да.

- Ну, давайте вопросы.

- Ну, собственно приветствие.

- Приветствие - здравствуйте-здравствуйте!

- Добрый день - добрый день! Естественно, дорогие читатели, нас будут читать. Сегодня мы в гостях, а точнее я в гостях у Вас, Елены Теодо- 
ровны Лобачевской. «Милой Государыни» - это цитата из книги.

- Милостивой, да. Милостивой Государыни. Преподаватель ВГИК..

- Я - не преподаватель.

- $\quad$ В прошлом, в прошлом.

- В далёком - да.

- Но тем не менее.

- В 90-е годы.

- Писатель-сценарист..

- Я - не писатель.

- Ну, а как же сценарий к «Аленькому цветочку»?

- Я вас умоляю. Это не повод, нет. Вдовы Валерия Золотухи. Всё.

- На этом закончим Ваше описание?

- Конечно, да.

- Потому что у меня дальше идёт...

- Не надо. Вдовы Валерия Золотухи - всё. Всё остальное вычёркиваем.

- Отлично. Ну... а потом была пафосная фраза, которую я создал: «Широкая сфера деятельности Елены Теодоровны ограничивается...».

- Да нет никакой деятельности!

- ...единственными рамками, имя которым - искусство и культура.

- Ой, не надо!

- Не надо? Значит без пафоса.

- Не надо, без фигни вообще, все оценочные суждения всё убираем, не нам судить.

- Самый банальный вопрос - как начался ваш творческий путь и как он изменился, в какую сторону он изменился после появления в вашей жизни Валерия Александровича?

- Ой, ну мы познакомились с Валерой Александровичем в 90-м году. Вот. Мне было 30 лет, ему - 35. Мы были весёлые и легкомысленные. Мы очень мало говорили о творческом, о творческих путях. Мы были очень рады, что мы друг с другом познакомились. Действительно, нам друг с другом было весело и очень хорошо. И... мы очень легкомысленно сошлись и совершенно не думали, что это потом станет... Мы влюбились друг в друга, была любовь, всё, но... не строили никаких планов, совершенно и не думали прожить всю жизнь, потому что у обоих характеры были достаточно сильные и такие самодостаточные. Но так случилось, что с каждым годом мы любили друг друга всё больше, и становилось всё как-то интереснее и лучше жить. И Валера настолько талантливый человек, что я как-то о своём творческом пути не думала, мне было очень интересно с ним. Общаться, жить. Мне очень нравилось то, как он пишет, поскольку я окончила сценарный факультет ВГИК, мастерскую Евгения Алек- сандровича Григорьева, а защищалась у Валентина Ивановича Ежова. У меня были очень хорошие учителя, они были очень талантливые и одновременно очень яркие, благородные великодушные мужчины. Мы, например, когда Валера в 94 году на конкурс «Семени фильм», который американцы у нас проводили на «Приз Эйзенштейна», написал сценарий «Великий поход за освобождение Индии»... И очень быстро написал, за три недели, и получил первый приз - «Голливудс филмз». Это одна из голливудских студий была, это «Семени фильм». Он получил приз, и потом этот сценарий в виде повести напечатал журнал «Новый мир». Мы послали этот сценарий с дарственной надписью моему учителю Евгению Александровичу Григорьеву - замечательному драматургу, автору книг «Три дня Виктора Чернышёва», «Романс о влюблённых», моему учителю - просто в подарок, и первое, что сделал Женя Григорьев позвонил нам и поговорил первый со мной. Он сказал: «Молодец, разглядела парня!». Так как он - очень добрый великодушный человек, он не мог меня просто похвалить за то, что я после ВГИК написала 10 прекрасных сценариев, он похвалил меня за то, что разглядела парня. Потому что ему понравилась очень эта Валерина киноповесть, и он был очень рад, что он хороший парень, талантливый. Так... Насчёт творческого пути... мы просто жили, иногда весело, иногда преодолевали какие-то трудности, но нам было хорошо вместе, и работать... Но работать не над серьёзными произведениями, а вот если подработать - заработать денег, было весело, если я доставала какой-то там заказ или что то, мы с удовольствием... Валера мне всегда помогал, мы вместе делали. Монтировали кому-то за кого-то фильмы, ездили в Питер, просто вместе зарабатывали денег, но всё больше и больше... Поскольку Валера - очень яркий и талантливый драматург, я видела, что как-то ему уже тесны рамки кинодраматургии и что он хочется состоятся как писатель. Валера всегда говорил: «Хочешь чтобы было хорошо? - Сделай сам». А вот когда ты пишешь сценарий, ты не отвечаешь за конечный продукт. Я должна сказать, что при всём при том, что были хорошие фильмы по Валериным сценариям, сценарии-то были если честно - лучше.

- Следующий вопрос, как раз, идёт про фильм «Мусульманин». Я посмотрел, это шедевральный фильм.

- Сценарии был ещё лучше. «Мусульманин» - хороший фильм, а сценарий был гораздо круче, вот не потому, что это мой муж, а правда, объ- 
ективно, сценарий был... Володя Хотиненко человек достаточно комфортный, и он смягчал, смягчал, смягчил монолог Федьки брата, он смягчил финал. У Валерки гораздо всё резче. Вот. И те, кто читал эту повесть - «Мусульманин», все... ну просто ни у кого сомнений нет, хотя «Мусульманин» - хороший фильм. Вот. И когда Валера сказал мне про свой замысел «Свечки», я ответила: «Пиши!», потому что в кино всё переходило на коммерческую основу, все драматурги не могли уже... очень редко могли... работать в кино... и шли писать сериалы. И мне было так жалко Валеру, а ему было жалко себя, потому что истратить вот этот дар драматургический, который тебе послан, на написание сериалов - это кончено очень... грустно. И дело в том, что кино очень изменилось. Были всё-таки главные люди - сценарист и режиссёр. Их уважали, они считались творческими личностями, у которых было и самоуважение и их уважали. С приходом так называемого продюсерского кинематографа, который не имеет ничего общего с западным продюсерским кинематографом... Просто на Западе продюсер - это человек, который генерирует идею, находит на воплощение этой идеи не только деньги, но и творческие кадры, всё. Это творческий человек. Просто тот творческий человек, который ещё знает, где взять деньги. Вот и всё. Он бы мог об этом не думать, но он знает, и всё знает, но он - творческий, он - талантливый человек. У нас продюсеры - это в большинстве в своём жулики. За каким-то редким исключением. Это люди, которые хорошо если с директоров картин пришли, потому что директора картин любят кино, они заканчивали кино-институт или что-то подобное. Директора картин хотя бы любили кино, а тут пришли люди за лёгкими деньгами. В большинстве своём. Люди, которые могут взять госфинансирование, снять с него сливки, притом сливок слой очень толстый такой, а на оставшиеся что-то сделать. И им совершенно всё равно, каково качество этого фильма. Для них просто... это способ заработать денег, не более того, а люди, которые воспитывались, что кино - это искусство, они хотят больше... На первом месте, что-то создать, а потом уже заработать деньги. Вот поэтому такое кино - когда продюсер и сценарист нужны, как нужны какие-то гаечки и винтики для того, чтобы он заработал.

- В общем-то возвращаясь от продюсерства к «Мусульманину»...

- Да, давайте я договорю. И Валере стало неинтересно работать в этом кино. Кино, где его используют для того, чтобы кто-то заработал деньги и так и относятся. Относиться стали к сценаристам и к режиссёрам в кино, как к некой наёмной силе, без которой не обойтись, чтобы попилить эти деньги. И он захотел уйти оттуда. И встал вопрос, потому что Вы спросили вначале про мой творческий путь, и остался вопрос... И когда он сказал о замысле фильма «Мусульманин», я сказала: «Не волнуйся о деньгах, пиши заработаем». И я пошла зарабатывать те самые лёгкие деньги, потому что работа редактором в наших студиях, для меня это лёгкие деньги. Потому что, это вредное производство, потому что читаешь очень большое количество очень недоброкачественных текстов. Серёжа Сельянов, Наташа Мокрицкая - редкое исключение, которое делает хорошее кино. Если люди, которые думают о кино, а не о том, как срубить деньги... Ну, Валере это кино стало неинтересным, и когда я приходила со своими рассказами о своей деятельности на студии, я работала на очень многих студиях, чтоб мы жили достойно както. Хотя Валера тоже, когда он писал «Свечку», не то, чтобы он вообще не работал. Я просто, ну каждодневно, а он снимал документальные фильмы очень хорошие, когда ему предлагали, и конечно зарабатывал. Издавал книжки, да что-то, ну что-то... Если уходишь из кино, всегда мужчина боится - а как будет семья... Я говорю: «Спокойно!» И вот, я добывала регулярный заработок, работая на этих жутких студиях, но когда я ему рассказывала, ему это было уже не очень интересно, он всё больше и больше уходил в прозу и в другую... А когда он писал «Свечка», было огромное количество книг, которое он читал. Митрополит Антоний Суржский, Александр Шмеман, - это был вот тот круг общения, на тот момент, который ему был интересен. Поэтому после этого круга общения, тех книг, которые он читал, очень много книг и он очень за это время, конечно, очень сильно обогнал меня, по чтению, потому что он читал замечательные книги.

- Но, он читал то, что он хотел читать, а не как Вы. Вы читали то, что приходилось.

- $\quad$ Да-да-да, я читала, да, чтобы заработать деньги, жуткую какую-то киномакулатуру я читала, а он читал книги всё лучше и лучше. Он читал там, ну я не знаю, святоотеческие всякие писания, он читал книги по христианству, по православию, очень разные, не только... Он уже и иудаизм прекрасно знал, он знал очень много. Ему было все интересно, он читал литературу духовную. И ему... И он уже находился в этом круге общения, то есть в идеологии этих лю- 
дей. Поэтому общаясь с киношниками, он после этого... было... Ну выпить иногда приятно, симпатично, но уже о чём-то поговорить, конечно было трудно. Поэтому он уходил, уходил, уходил, уходил. Конечно круг у нас был огромный круг друзей, всегда стол расставлялся, столы по 20-30 человек в 90-е годы. Все праздновали, каждый раз.

- Прямо здесь?

- $\quad$ Здесь! Это же сороконожка, она же расставляется, в неё вставляются ножки.

- Я просто представляю так на 20 человек стол.

- Нормально раздвигается вот сюда, но была другая планировка здесь. А вот в 2000-х всё это стало уходить, это общение, и жизнь становилась более замкнутой. Но, с удовольствием конечно, мы ездили за границу, и Валера открыл для себя Италию и очень полюбил, очень полюбил Италию и Париж, конечно вот это было счастье - посмотреть мир, за это время. Он ушёл из кино в 2000-х. В 90-х у нас была замечательная мастерская во ВГИКе, а 2000-х вовсе уже все были посвящены «Свечке». Нет, ну есть ещё несколько документальных фильмов, которые он делал от всей души, три фильма церковных - «Попы», «Ангел русской церкви против отца всех народов» и «Ребро: портрет жены художника на фоне эпохи» - это всё фильмы о священниках, очень хорошие, он их делал со всей душой.

- Я смотрел один из них.

- Какой?

- «Ангел русской церкви против отца всех народов».

- $\quad$ Да? И два фильма о художниках: «...я тебя увековечу» Анатолий Зверев, и «Художник Дмитрий Плавинский» - о Плавинском соответственно. Он тоже делал эти фильмы с большим увлечением, со всей душой. Но конечно это было не основное его занятие... Получал призы за них...

- Нет, ну одним делом заниматься на протяжении 12 лет - это очень сложно, конечно.

- Да, он отвлекался, делал фильмы.

- Вот бы всем так отвлекаться!

- Да.

- Возвращаемся в 95 год, то бишь до 2000-х годов, до ухода со сцены кино. Мусульманин - одна из сильнейших картин, одна из тех картин, которые признаны, и они являются, я считаю, не настолько испорченными экранизацией.

- Да, он даже получил «Ника» за этот сценарий.

- Фильм актуален на протяжении всего периода времени, с момента его создания.

- Да-да-да, даже сейчас американцы сделали фильм «Родина».
- $\quad$ Сегодня мы смотрим и никакой разницы не видим, то есть, все проблемы, описанные и там, и все столкновения идеологии, они на сегодняшний день остро актуальны. Как пришла идея? Идея создания такого сценария.

- Валера очень много говорил об этом в интервью, его очень часто об этом спрашивали. Он увидел сюжет по телевидению, по-моему, по каналу «Россия», как возвращается парень к матери мусульманином. Он увидел сюжет в новостях.

- $\quad$ То есть это реальная история, которую он развил.

- Сюжет в новостях, да. Не развил, он его придумал, это был толчок. Вернулся парень, который принял мусульманство, - это маленький сюжет в новостях.

- Участвовали ли Вы в создании сценария?

- Нет, конечно.

- Экранизация, мы уже затронули тему, что экранизация немножко смягчила...

- Фильм? Да. Да, она смягчила, ну как... Это хороший фильм Володи Хотиненко. Но, если вы прочтёте повесть «Мусульманин», там всё ещё острее.

- Ещё острее?

- $\quad$ Ещё острее. И монолог Федьки и финал, когда его убивают, там поострее.

- Если говорить о доступности, то доступен именно сценарий работы. Как допустим книгу найти? Потому что нереально. Вот я смотрел в интернете - очень тяжело.

- «Мусульманин» напечатан, издательство «Вагнер» 2000 года.

- Но найти его тяжело.

- Нет. В интернете?

- Я его искал, найти его тяжело.

- Понятно, что не просто. Сейчас выйдет избранное, в издательстве «Время». Оно уже готово, там только обложку делают.

- Мы можем следующее интервью сделать - рецензия на избранное?

- Следующее интервью. Избранное... Вот, пожалуйста, выйдет, тогда можно будет обсудить это.

- Тема идеологии, политики, религии, они затронуты как в «Мусульманине», так и во многих других работах. Не беру в пример сейчас сразу «Свечку», это мы оставим на потом. Но вот, я посмотрел «Ангел русской церкви против отца всех народов», и у меня сложилось впечатление что, даже моё поверхностное знакомство с творчеством Валерия Александровича, должно рассматриваться в совокупности, то есть я фильм «Мусульманин», то есть картину «Мусульманин», воспринимаю только в связке 
с «Ангелом русской церкви против отца всех народов», то есть...

- $\quad$ Хотя разница между ними лет восемь.

- Разница колоссальная, и временная разница описания событий, и сюжетность, и по сути всё разное, о разных вещах, но всё объединяет борьба идеологий, борьба с религией, борьба религий, .... собственно и вопрос то я забыл.... Темы идеологии политики и религии - одни из самых острых на сегодняшний день...

- $\quad$ А почему на сегодняшний день?

- Ну... на протяжении всей жизни человечества, если на то пошло...

- $\quad$ В общем-то да, в общем да.

- Фильм «Ангел русской церкви против отца всех народов» - 2005 год, документальный фильм, в котором Валерий Александрович выступил как автором сценария, так и режиссёром, на мой взгляд, очень сильная лента, как самостоятельно, так и в тандеме с картиной «Мусульманин», как некая историческая справка о причинноследственных связях падения духовности в обществе. Уместно это сравнение, как Вы считаете?

- Уместно.

- И были ли трудности, касательно документальной ленты, с архивами, с доступом к архивам?

- Нет, нет. Никаких трудностей не было, потому что он снимал эту картину на студии «Православная энциклопедия», художественный руководитель которой Сергей Леонидович Кравец, он - главный редактор «Православной энциклопедии», поэтому никаких сложностей доступа к архивам не было. Была некая неполная информированность.

- Намеренная или случайная? Я понимаю, что случайностей не бывает, но тем не менее.

- Мне трудно ответить на этот вопрос, потому что «не пойман - не вор», но Валера потом переживал. Он был не до конца информирован. Ему предоставили все материалы, и он сделал такой фильм. В общем, он отвечал, и мы с ним ездили на просмотр. Но мне он говорил, что, конечно, мне дали не весь материал.

- Но материала дали много тем не менее?

- Много.

- Я просто смотрел, очень много.

- Нуне всё, не всё. Потому что слишком противоречивая фигура отец Сергий, понимаете, он всё таки пошёл на сговор с советской властью. И очень многое. Валера сделал фильм. Зато он сохранил церковь в России. Но очень многие, очень уважаемые люди в церкви ему это не простили, этот сговор с людоедами. Это сложно...

\section{- $\quad$ Сговор ли это?}

- Ну, считали что сговор. Валера сделал фильм, там же не зря его голос за кадром. Он пробовал, он пригласил Сережу Маковецкого. Пробовал записывать - не получалось, и Сережа говорил: «У меня не получается». Он пробовал ещё одного актёра и тоже не получалось. Он пробовал, а я его уговаривала: «Сам». Потому что он боялся: «Я зажимаюсь, голос зажат». Я говорю: «Это на фильм будет играть». И он в конце концов сам записал, от себя. Там в этом фильме поставлен очень сложный вопрос, тот вопрос, который перед нами всеми стоит и поставлен ещё Пушкиным: «Можно ли молиться за царя?». Иродливый говорит, что нельзя молиться за царя иродов. А наша церковь всё время молится за ирода.

- Мне очень понравилось, понравилось, ответ понравился про одеяние. Намёк с одеянием, когда подарили...

- Ты не можешь его судить...

- Попробуй судить человека, только взяв его ношу на себя.

- Да-да-да. Фильм этот делает Отец Сергий Правдолюбов. Потому что Отец Сергий Правдолюбов - это такая потрясающая личность. Это его биография, четыре поколения священных. Он сам талантливая личность. И, конечно, его слова, да. Они правильны.

- Я считаю, это и есть основа всего фильма. Потому что во всём фильме, мне что понравилось, во-первых, не высказывается чёткое мнение автора по этому вопросу, то есть Валерий Александрович чуть отошёл в сторону, и передаёт поле нам. Но когда под конец уже, когда казалось бы, а вот всё таки что нехорошо... И тебе дают эту часть интервью, где описывают опыт с одеянием...

- Да-да, вы правы.

- Это расставляет всё на места.

- Да-да, ну Валера, я помню, я помню, что он переживал касательно этого фильма. Потому что он говорил: «Они не дали мне всего»...

- Ну, возможно не дали по причине того, что у них было мнение на этот счёт, которое они не хотели высказывать в открытую.

- Он потом что-то читал и говорил: «А-а-а, они мне этого не сказали, а-а-а, я не знал». Он же не режиссёр, он не знаток, ему дают материал, материал, материал, и он выстраивает. А потом он читал какие-то вещи и говорил: «Я не знал, ох, я не знал...», то есть он переживал, потому что тема сложная и ужасно актуальная.

- И при этом не затрагиваемая... 
- Именно потому, что безумно актуальная. Ну хотя... Был фильм Хотиненко «Поп». Когда священник в немецкой оккупации...

- Но это художественный фильм.

- Да, художественный фильм. Тот же вопрос в нём. Вопрос очень сложный. Очень сложный и не имеющий однозначного ответа. А священники как во время оккупации? Валера отвечал, что им можно всё простить - то, что они окрыляли пленных, они были единственной какой-то надеждой для этих несчастных людей в общем.

- Опять же вернёмся к фильму «Ангел русской церкви против отца всех народов». Когда говорили про чтение литургии перед ранеными... и показаны документальные кадры, где не то что поля, а безграничные поля пленных, раненных, полуубитых людей, читать литургию в таких условиях, и вообще остаться святым... Это опять же... Это ноша, которую нужно примерить на себя и ответить на вопрос - а возможно ли?

- Сам вопрос очень тяжёлый.

- Валере очень тяжело дался этот фильм. Он начал болеть, когда его делал. Что-то с давлением. Это было очень тяжело. Потому что на этом столе лежали десятки книг. Это были книги о новых новомученниках, я это просматривала, Валерка читал всё это. Монах Домоскин, замечательный человек, он был у нас дома, и вот эти книги о всех замученных Сталиным, Лениным, все их биографии, лежали. Огромная стопка на этом столе. Он их всё прочел. Это очень тяжело.

- $\quad$ Это надо пережить.

- Постоянные думы - отказываться или не отказываться от этого фильма. Загремел в больницу. То есть это было всё не просто, потому что пропустить через душу такое... Вот материал, это великий подвиг монаха Домоскина, который всё это сам собирает, до сих пор он... это всё новомученники. Все вот такие книги, биография, житие новомучненников. Потому что то, что в стране произошло - это действительно страшно. Какое количество монахов, священников были убиты. Этот фильм получил гранпри на международном фестивале православного кино в Киеве. Мы ездили в Киев в Лавру, блаженный Митрополит Владимир Киевский вручил Валере гран-при за этот фильм на международном православном фестивале в Киеве. Ещё где-то в России он получил приз, в Свердловске на фестивале он получил приз за очень хорошее использование хроники.

- Очень хорошее, шедевральное использование хроники.

- Какой-то специальный приз дал кинохит за использование.
- $\quad$ Это очень хорошее документальное кино.

- А вы знаете документальное кино находится во много лучшем состоянии нежели художественное, потому что, больше можно сделать и сказать. А вот фестиваль был - «Артдокфест». Битком залы, билетов не достать. Пустые залы на игровое кино и битком заполненные залы на документальное. Потому что людям интересно то, что актуально.

- Подходим к роману «Свечка». 2001-2014 год указано в официальных источниках. Я так понимаю, задумка написать появилась намного раньше.

- Ну да, но приступил он так уже плотно, где-то в 2003-ем. Он был уже в 2000-ом году в «Новом мире» и думал, что он за год напишет.

- Это же был куличик...

- $\quad$ Он зашёл в храм, ему пришла в голову идея романа. Только что как раз вышел «Последний коммунист» в «Новом мире». И его спросили: «Что у вас будет дальше?». Он сказал: «Да-да, я придумал, сейчас буду писать». И уже в «Новом мире» 2000-го года, весь 2000 год выходил анонс «Залотуха “Свечка”». Готовится в публикации. И он в этом увяз. Первая часть, за ней потянулась вторая, и роман рос как на дрожжах. А параллельно в 90-х Валера строил дом в деревне, и когда он строил этот дом, я приезжала, смотрела на эту странную конструкцию. Он разводил руками: «Ты знаешь, дом сам себя строит. Роман тоже сам себя строит. Я думал за год, я только за два года переписал первую часть», а потом третья, а потом четвёртая... и уже где-то спустя 10 лет - весь в романе. 0 н мне сказал: «А ещё эпилог. 0 чём ты думаешь будет эпилог?». Он сам себя тоже, вот он как-то сам себя строил этот роман. И Валера только слушался какого-то голоса, что надо вот так и так. И он рос с этим романом. Он писал этот роман. Он очень рос духовно, как мыслитель, как человек, который ставит себе большие задачи, и эти задачи человека вытягивают. И он поставил себе большую задачу, и она его всё время тянула.

- $\quad$ Это ещё и трудно в том плане, что страна переживала не лучший период. С 2000 года по 2014 год. Страна изменилась и очень сильно. Влияние этих изменений на роман? Смена мировоззрений, взглядов - повлияло?? Потому что описаны 2000 года.

- Описано начало 90-х.

- Да, с начала 90-х по миллениум.

- То, что произошло в 2000-х, это имеет корни в 90-x.

- $\quad$ На сегодняшний день, мы живём в 90-х по сути. 
- Нет-нет, на сегодняшний день мы живём никак не в 90-х. 90-е - это были свободные годы. Это были годы безудержные, но свободные. Там была свобода печати, там была свобода, которой люди не умели пользоваться. Она переходила во вседозволенность, безумие и распущенность.

- $\quad$ Но это уже шальные 90-е.

- Да-да. Но они были. Валерка считал их счастливыми, эти 90-е. Валера был уверен, как уверена и я, что в истории России обозримой, которую мы видим, мы не знаем, как там было в Новгородской Республике, мы себе не очень хорошо это представляем. А вот в обозримом пространстве это одни из самых свободных лет в истории России... Да такие. Да, они были диковатые, но они были свободные. Эта страна, вот с такой улыбкой, как у вас сейчас была. Люди ходили по Москве, в них поселилась надежда, что мы сможем жить как нормальное цивилизованное человечество, что мы - не рабы.

- В эти достаточно свободные годы создалась очень тяжёлая картина того времени - «Мусульманин». Описывающая очень...

- В таком состоянии страна пришла к этим свободным годам. Они же не были идеальными. Идеального мира нет, но они были нашими в жизни. В нашей жизни, людей, родившихся в 50-60-е годы, они были самыми счастливыми, потому что были напечатаны все книги, которые мы любили, да, мы читали их через синюю копирку, но большое количество людей не имело этой возможности прочесть. Также стало возможным создать свою фирму, своё дело. Нельзя было при советской власти. Действительно в 90-х не было политических заключённых. Их, правда, не было, выпустили всех. А страна по-другому дышит, если в ней нет невинно осуждённых. Кому-то, может быть, всё равно. Нет, не всё равно. Когда какая-то несправедливость, жестокость - это в воздухе, и дети эти воздухом дышат. И человеку может казаться, что наплевать, но ему не наплевать, воздух... он отравляется этой несправедливостью. Как бы ты от себя эти мысли не прятал... В 90-х годах не было политзаключённых.

- Но ведь мы на сегодняшний день вернулись к этому, у нас снова появляются политзаключённые.

- Конечно.

- Поэтому когда вы сказали, что мы в 90-х...

- $\quad$ Э, нет! Мы - в 2015, а страна откинута в чём-то в 77, в чём-то в 73, а в чём-то в 52-53.

- $\quad$ Вы не сказали 30-е, мне полегчало.

- 30-е - это годы массовых репрессий. Когда сидят миллионы, это отличается, когда сидят сот- ни, хотя когда сидит несправедливо один человек... Возвращаясь к разговору: связь времени и творчества Валеры с идеологией. Любое литературное творчество актуально, потому что человек живёт в мире. И любое хорошее литературное произведение - оно многослойное, оно затрагивает и вечные проблемы и свидетельствует о времени и мире, в котором живёт писатель, потому что... замечательные слова: «Герой заходит в туалет и видит надпись “В чём смысл жизни?”, берёт какой то мелок или фломастер и пишет: “Быть глазами, ушами и совестью создателя вселенной, дурак ты этакий!"». Вот смысл писателя - чтобы быть глазами, ушами и совестью создателя вселенной, это некий отчёт Господу Богу о том, что он видел в этой жизни, что он из этого понял и что он может рассказать Богу и людям из этого. Наверное. Ну, вот Серёжа Домбровский говорил: «Совесть - орудие производства писателя». То есть человек бессовестный, наверное, не может быть хорошим писателем, потому что совесть это есть то, что заставляет...

- А тут у нас тонны макулатуры в книжных магазинах.

- $\quad$ Они просто бессовестные. Они решили к этому относиться как к ремеслу, ну это макулатура, но мы не знаем этих имён и их не запомнят. Макулатура уходит.

- $\quad$ Я сейчас перейду к тематике, которая меня возбудила до степени, чуть ли не гнева. «Новый мир» - заинтересовался, зашел в «Википедию», посмотрел о журнале, там указан тираж: 91 год 3500000 шт. 2015 год - 3500 шт. И зайдя на отчёты одного глянцевого гламурного журнала, журнала, что на всех прилавках, - тиражи десятками миллионов. Приходит понимание, что люди не оцифровывают эту макулатуру вообще.

- Это цена свободы. Это свободный выбор.

- $\quad$ Это подтверждение ваших слов про 90-е.

- Я всё равно выбираю свободный выбор. Пусть будет у тебя 200 читателей, это что-то из моей жизни и она окажет какое-то влияние. Всётаки, конечно, хорошо, когда миллионы..., конечно, женщине интереснее читать, какие модны сумочки, чем бередить душу трагичностью бытия. Конечно. И, слава Богу, всё равно есть читатели у всех. Литература - вообще искусство, не имеющее количественного показателя. Нельзя измерять количеством. Измерение количеством... Сколько человек читало Евгения Онегина в то время? Наверное, несколько сотен. В то время, несколько тысяч максимум. Но, я думаю, несколько сотен просвещённой публики. Зато этот роман читают миллионы 
на протяжений столетий. Понимаете? Так что это всё зависит от того, как будет развиваться Россия. Когда мне говорят: «Молодёжь не читает!», то возникает вопрос: «Какая молодежь?». Кто читает. А кто не читает. Это всё нельзя так обобщённо обсуждать. Всё равно книги будут писать и будут читать. И будут книги, которые будут иметь большие тиражи, и их через два года забудут. А будут книги, которые имеют небольшие тиражи...

- А потом за ними будут гоняться...

- Конечно! И по ним будут судить о времени и о нас. И это будет нашим, и мы будем запечатлены.

- $\quad$ Тогда про миллениум у нас есть, почти инструкция, можно сказать, в двух томах.

- Да-да. Очень замечательная трогательная показательная история с Гроссманом - «Жизнь и судьба». Как человек написал роман, в котором опередил своё время по мысли очень сильно. Потому что сказать в конце 50-х годов, прийти к мысли, что, что фашизм, что коммунизм одно другого стоит. И этот диалог, когда фашист говорит: «Мы учились у вас». В конце 50-х годов!

- $\quad$ Это выйти за рамки в общем двух держав.

- И человек написал такой роман. И у него арестовали этот роман. Он умер от рака в возрасте 60 с небольшим лет. И эта история всегда сжимала сердце. Написать такой роман и умереть. Роман арестован. Он где-то там, в этих жутких подвалах. Прошло время, и этот роман - бестселлер в городе, в Англии, в Лондоне. И в России тоже напечатали, и даже вышел сериал, правда, где убрали все главные мысли романа, всё есть, кроме двух главных линий, а всё остальное прекрасно. И когда я слышала, что бестселлер сейчас в Англии - «Жизнь и судьба» Гроссмана, у меня искреннее потекли слезы, и я улыбнулась: «Валерка, слушай - это бестселлер». Потому что он сделал радиопостановку в Англии, и весь Лондон встал за «Жизнь и судьба». Бедные советские заключённые и бедные советские евреи - им это стало искренне интересно. И столько лет книга жива. Книга измордованная, закопанная где-то там у друзей Гроссмана. Похороненная в этих КГБ-подвалах, а всё равно она победила. Сохранили друзья, которые где-то держали на даче и позже через границу по возможности передали. Поэтому действительно по Булгакову: «Рукописи не горят», - хотелось бы на это надеяться.

- Я уже знаю, что тираж прошёл первый, второй. Я уже видел у людей с пометкой «Большая книга».
- Да уже. 5000, если раскупят, сделаем ещё и должно быть ещё «Избранное».

- У меня вопрос про то, что пока я читал... Я не жил в 90-х. Я жил осознанно с 00-х по 15-е, сегодняшний день. То, что написано, - про сегодняшний день. Опять же вседозволенности и условий свободы, которая ещё там сохранилась... Сегодня все пресекли, но это моменты, общая картина осталась той же. У меня был вопрос: мы его уже обсудили, я его формально повторю - мы выходит что только сменили обертку, а начинку оставили той же? Опять же это вопрос про корешки из 90-х. Неужели настолько мы не смогли... вот так не смогли, на основе этой свободы, прыгнуть выше, чем были.

- Да.

- Мы как-то возвращаемся к тому же на круги своя.

- $\quad$ Это очень трудный вопрос. В 90-е - счастливые свободные годы, но одновременно... Народная совесть не выдержала испытания свободой. Чья-то же выдержала. Конкретные люди, те люди, которые оказались у власти, не выдержали испытания свободой. Они стали хватать. У них не было чувства ответственности. Все за эту свободу пришли в 91-ом году к Белому дому. Вся Москва. Там были все. Не хотели снова в совок... Дальше люди, получив доступ к этому... У них не было чувства ответственности, совести. Не надо было всё себе хапать, надо подумать о людях... Надо подумать. Они совершенно, наверное, хорошие образованные люди, получившие образование по хорошим американским учебникам экономики, но вот у них не было развито чувство сострадания, совести.

- Винить в этом их нельзя, потому что так они выросли и так воспитаны...

- Нельзя, они занимались экономикой, но всё это нельзя было настолько забыть. 0 том, что нельзя в своих расчётах, чтобы моя экономическая программа предполагала, что столько-то тысяч должно умереть с голода... Нельзя. Ты должен поделиться, наверное, своим и сделать всё, чтобы они не умерли. Твоя программа, наверное, правильна, но за рамками этой программы оказываются эти одинокие жертвы.

- $\quad$ Реальная жизнь за рамками.

- Да, чтобы о них не говорили, хорошие или плохие. Нельзя их обречь на смерть. Ты должен, как я очень примитивно говорю, но по чувству, ты должен сам и твои друзья - мы должны помочь. Не должны оставить их так. Они не должны голодать. Это аморально. Учительница, которая учила меня в школе, пусть она говорит, что Сталин - великий, а Брежнев - прекрасный, 
но я не позволю, чтобы она голодала. Вот тогда, когда эта совесть у людей стала работать, мы бы вышли достойно из 90-х и были хорошей европейской свободной страной. Действительно, я и читала очень многое про это время, и люди пишут, что генофонд нации был уничтожен. Лучшие погибли на Отечественной, лучших Сталин уморил в лагерях. Остался-то материал не очень. Лучшие остались там, лучшие погибли. «Папа мой, мастер Женя Григорьев, очень переживает и очень страдает от того, что он не успел на войну». Родившиеся в середине 30-х все переживали, что не успели повоевать, потому что для них герой войны был романтикой. И папа сказал: «Ой, слава Богу, что Женька не успел, такие, как он, погибали в первом бою. Честные, открытые, смелые, которые шли добровольцами, такие, как он, погибали в первом бою. Лучших выкосило. И война, и Сталин». И уехали. Талантливые, очень много уехали, понимая, что здесь им не пробиться, что здесь они со своими талантами техническими, научными, обречены на нищету, они уезжали. И остались люди, которые... К власти пришли бы нормальные люди, которые любят книги, науку, нечего делать им во власти, у них есть масса дел, чем заняться в жизни. Они и не приходят к власти. А уж те, кто рванули к власти, уж совсем бессовестными оказались. Ну, просто, давайте настроим себе здесь три дома, на Лазурке три дома, в Америке. Задница одна, ноги две, руки две, ну как ты? Я была на Лазурном берегу, видела эти дома, французы смеются над ними. 3000 кв. м. у тебя дом, как это убирать? Как жить? Просто не жилые комнаты, паутины. Какой-то беспредел. И одновременно... Нигде кроме России, Индии и Африки нет такого расслоения между богатыми и бедными. И чтобы вернуться к «Свечке»- Золоторотов - дети и старики, у него две заботы. Он же не говорит много о религии, православии. Дети и старики. Самые незащищённые. Нельзя жить благополучно, о них вообще не думать.

- Он же и описывает в своих рассуждениях: власть - старикам, детям ещё рано, а старикам можно, амбиций уже нет, спокойно и размеренно они решат свои вопросы. Это мне очень тоже понравилось.

- А эти дети и старики нашей властью были забыты. Забыты. Это была Валерина боль. Я пыталась рассказать на Большой Книге - вот этот город Елатьма, куда со всей России свозили больных детей.

- $\quad$ У меня, не поверите, следующий вопрос про Городище.
- $\quad$ Это Елатьма. У нас дом в деревне Бурдово под Касимовым. И рядом город Елатьма. Город, где история Городища описана в романе. И город, в который, там всё описано в романе, со всей России свозят и свозили больных, никому ненужных детей. И там же есть ин. дом - инвалидный дом, престарелые и дети совсем больные. В 17 лет сразу в ин. дом и там умирают. И Валера настолько переживал это, он делал всё, что было в его силах, чтобы помочь этим детям. Он очень хотел снять ещё один документальный фильм, договорился, придумал его весь. Фильм назывался «Любят Россию». «Любят Россию» - потому что видно, что в этом детском доме дети лежачие, без ручек и без ножек, самоесамое ужасное, что может быть. Туда каждое лето... Вдруг раз, и он видит таких длинномордых тёток, каких-то господ, мужчин, в каких то шляпках - англичане. Англичане в свой отпуск, приезжали туда, чтобы помогать нашим самым несчастными обездоленным детям, носили их на руках, гуляли с ними и назвали своё общество - «Любим Россию».

- Это страшно.

- А Валерка хотел сделать фильм - «Любят Россию». Договорился уже с оператором, техником, говорил мне: «Я этот фильм уже вижу, я его сделаю, бесплатно буду работать, но этот фильм сделаю». И назвал его «Любят Россию». А Валера - очень открытый человек, очень. Ко всем людям относился очень доверчиво, и он рассказал, что я буду снимать с такого-то дня. И он мне звонит, а я в Москве организовывала выездную группу - оператор, свет, ассистенты, это же надо кино снимать, не на один день едем. Взяла хорошего оператора, заплатила за технику - и вдруг Валера звонит, он был убит этим - им не дали визу. Им не дали визы. Я говорю: «Твой язык! Зачем ты лишнее говорил?». Им отказали в визе, всем! Кто-то услышал Валерку и им всем отказали в визе. И эти дети остались без этой английской помощи... Потому что собирали весь год деньги, летом в отпуск приезжали, и там строились беседки... И всем отказали в визе. Ну, мы нашли... Моя подруга, так как состоятельная женщина, и она помогает этому детскому дому. И Валера всегда... Мы ездили, покупали всегда еду, игрушки, старались всегда найти какие-то спонсорские деньги, помочь. Это страшно, действительно страшно. Это страшно даже войти в этот дом, это надо усилие, надо быть мужественным человеком, Валера входил. Он говорил: «Я готовлю себя чтобы войти вот в том дом - старики и дети». Все эти дома очень хорошо описаны у 
Роберта Гонзалеса «Белое на чёрном». Книжка, которая получила Букера. Вот там всё описано.

- Именно это место?

- Нет, такое же. Практически такое же. Белое на чёрном.

- Вы рассказали и теперь мой вопрос.

- Говорите-говорите.

- Первое, исходя из того что вы сказали - нет ли у вас желания закончить работу, сделать эту работу, этот документальный фильм?

- Нет, я не режиссёр. И потом всё, англичане уже не ездят.

- $\quad$ Ну, это же не вечно.

- Нy, тогда когда-нибудь что-то произведётся. История, которая Валеру потрясла, - «Любим Россию». Кто любит Россию, для чего? А мы? Они любят наших детей, они любят этих детей. Русские, хотя не в национальности дело, бросили этих детей, больных, беспомощных, привязанных к кроватям. А англичане летят через весь мир, чтобы с ними понянчиться и привезти денег, чтобы они кушали хоть что-то. Это кошмар! Это кошмар жизни нашей. Это за гранью. Валера уже больной ходил на митинг против этого антисиротского закона. Видел в глаз этих детей. Там им сделают протезики, там их будут любить, там есть медицина, которая им поможет. А здесь их аккуратненько в 17 лет перенесут в инвалидный дом на второй этаж, и они там умрут. И эти бессовестные люди поднимают руку за этот закон. Они думают, что они будут прекрасно жить, после того, как они подняли руку за этот закон, я уверена, что нет. Я уверена, что не будут они хорошо жить. Как очень хорошо врач-онколог сказал, когда они отменили онкологическую программу в России, я читала где-то в интернете, врач-онколог сказал: «Они думают, что успеют долететь до Германии или до Америки? Я говорю, не успеют». «Не успеете!», - сказал врач-онколог. Нет лекарств. Мы это прошли.

- Не является ли этот Городище, помимо того, что это описание реального места - Елатьмы... Не является это ещё и метафорой к стране?

- Это всё-таки судить литературоведам. Вообще хорошее литературное произведение всегда метафорично. Наверное.

- $\quad$ Но всё же. Не являемся ли мы покалеченной страной и духовно покалеченными людьми?

- Нет-нет. Если бы эта история была только про этот детский дом и интернат, то да, такие истории всегда метафоры. Но роман всё же не об этом.

- $\quad$ Но Вы же понимаете, что роман огромный, и по сути выбрав любой блок наугад... По сути мож- но применить как метафору. Когда я читал про Городище, меня и так холодный пот прошибал, потому что описано, более чем правдоподобно и жутко при этом, поэтому мне пришла мысль сравнить нас, покалеченных людей покалеченной страны, и Городища.

- Нет-нет, я не считаю так. Этот роман и отличается этим. Он рассказывает о тяжёлых вещах, лагере, городище, там много тяжёлых вещей, но при этом роман то светлый, там нет чернухи, там полно надежды, там есть выходы всегда. Там нет чернухи.

- Если брать манеру написания романа. После прочтения первой части, переходя ко второй, а следом к третьей, мне каждый раз... Я начинал читать и каждый раз - это будет хуже, чем первая, это другой стиль...

- $\quad$ Все три в разной стилистике.

- И каждый раз... больше всего я не хотел читать зековскую часть, зековский сленг, зековский описания. Ветерок. Но когда я его дочитал, когда возвращался обратно в Москву, к Золоторотову, простому художественному повествованию, я понимал что это не то, и я хочу обратно...

- В зону, как там в зоне? Как Игорёк?

- Да-да. Насколько сложно работать всё-таки? Зековский сленговый, повествовательный художественный, прокуратуры язык - сухой документальный, и, я назову это - церковнохристианский. Переходы между вот этими частями, смешения их...

- Это и есть мастерство писателя. Это и есть. Каждый писатель ставит перед собой подобные задачи. Валера поставил перед собой очень сложные и интересные задачи - написать пять частей в совершенно разной стилистике.

- $\quad$ По отдельности я их не воспринимаю абсолютно.

- Когда человек пишет книгу всерьёз, он что-то хочет поведать городу и миру, и одновременно он хочет попробовать поставить себе определённые задачи: я с ними справлюсь или нет? Чем выше планка поставлена - тем интереснее самому работать. Поэтому Валера поставил себе такую планку - написать пять частей в разных стилистиках. Первая - от первого лица, вторая - чисто документальная, имитация документов, исходных, приходных, записок, статей.

- Замечу, что она не менее эмоциональна в прочтении.

- Третья часть абсолютно реалистичная лагерная проза, в общем, очень хорошо написанная. Четвёртая часть вообще - ты! Ты знал, ты думал. Пятая - появляется автор и встречается со своим героем. Он поставил себе такую высокую 
планку и поэтому он, наверное, и писал 12 лет, чтоб этой планке как-то соответствовать, первую часть он переписывал наверное раз 5-6. Он очень много переписывал, переписывал, переписывал. И вот, когда он уже был болен и когда вышло первое издание, он просмотрел его уже больным и: «Ох, я бы ещё четвёртую часть переписал. Знаешь, может я сам не смогу, ты мне поможешь, я бы четвёртую ещё раз переписал, и тогда была бы книжка, была такая, как я хотел. Ты знаешь какие-то вещи, по словечку». Это и есть работа писателя. Когда у нас начали писать на компьютере писатели - ну так оно и видно. Как известна байка литературная, что Толстому сказал Чертков: «Лев Михайлович, а Вы знаете, что Достоевский пишет ночами?». Толстой ответил: «Оно и видно». Люди пишут на компьютере - например Аксёновская проза, когда он писал от руки, а потом уже на пишущей машинке - отличается. Уже видно что «Московская сага» написана на компьютере. Это видно глазу. Любящему литературу видно, как человек писал. А когда проза, люди всё-таки переписывают, переписывают, я знаю, как Юрий Домбровский писал «Университет ненужных вещей». Ох, сколько переписывал, так оно и видно, что старался. Нет, к сожалению, это вот такая вещь, о ней Ахматова писала: природа дарования Моцарта и Сальери. И Ахматова про себя говорила: «Я - Сальери». По-моему, Ахматова, если не Цветаева. Потому что Сальери это алгебра, гармония и труд, а Моцарт - это вдохновение, сочинил за один раз. Когда мы преподавали во ВГИКе, я своим студентам говорила: «К сожалению, у нас в аудитории Моцартов нет, Моцарт виден, у нас все - Сальери».

- По тематике разных написаний у меня сразу возник вопрос. У нас наблюдается усвоение тюремных правил, отношений, канонов...

- Не только наблюдается, оно всегда было.

- Это просто становится не только навязчивым, это становится нормой общения. На фразу «Милостивый государь»- могут не только фыркнуть, да ещё и оскорбить...

- Это я-то милостивый!?

- Возвращаясь к «Свечке», по сути если закрыть глаза, между Ветерком, зековский тюрьмой и прокуратурой разницы то никакой?!

- Здравствуйте, капитан очевидность.

- Это, конечно, понятно. Но как введение в вопрос, я хотел бы это отметить.

- Конечно же. Они так и говорят: зайдите в нашу милицию, за редким исключением, они говорят как уголовники. Более того наш бизнес... Я общалась с продюсерами, у них такая же речь.
- Какие тенденции развитие культуры, на ваш взгляд, в этом контексте?

- $\quad$ Слияние уголовного мира и правящего класса? А какие тут тенденции? Это факт! Так и есть. У нас люди с уголовными наклонностями очень стремятся во власть, поэтому они говорят на одном языке. У нас правят в основном люди уголовного склада.

- $\quad$ А как с культурой языка?

- Они об этом не думают, о культуре языка. Ведь всё их косноязычие... вот наш начальник, оно очень простое имеет объяснение. Им надо чтонибудь... Раньше все обожали Черномырдина, все его высказывания и манеру - ведь очень просто ларчик открывается - на публике они не могут... Они привыкли материться в жизни, они через слово говорят мат, среди подчинённых, друг с другом, с начальством не всегда, правда. Когда у них берут интервью, они не могут сказать матом, отсюда всё их косноязычие. Они не знают, чем заменить эти слова. Они говорят практически матом. Очень большие проблемы с речью и выражением своих мыслей. Дома, среди товарищей и на работе они говорят практически матом - вот и всё. И когда интервью или какое-то публичное выступление или разговор с начальством... От этого такая скованность и косноязычие. Надо убирать эти матерные слова, и неизвестно что ставить. Тавтология и просто невозможность развить мысль. Это очень просто. Уголовники, в отличие от начальников, талантливее, среди них есть очень талантливые. Вот прообраз Игорька в «Свечке» - это был Ромка, парень, который освободившись из лагеря, пришёл к нам в гости, это был парень, которого можно было заслушаться, так он говорил. Хотелось включить диктофон и записывать. Это человек такого таланта. Он чувствует, как он говорит, среди уголовников очень много одарённых людей. Более талантливые идут в уголовники, а менее талантливые - в начальники. Люди одного склада - по моему наблюдению.

- Возвращаясь к культуре языка, чтобы подвести некий итог: выходит, что нам приходят уголовные правила, каноны? У нас идёт импортозамещение в обратную сторону, то есть все слова русские постепенно заметался англоязычными.

- $\quad$ Ну, это объективный процесс. Молодёжь воспитывается на компьютерах.

- Не много ли факторов, которые так активно разваливают русский язык? Ведь если человек, интересующийся литературой, прочитает роман «Свечка», он увидит в нём множество 
оттенков и сможет понять красоту даже зековского сленга. Он поймёт, что это тоже язык, это тоже пласт культуры. Человек же, который выращен на голливудских блокбастерах, прочитает и скажет, что это....

- $\quad$ Он не дочитает, но скажет много слов.

- Но ведь таких людей всё больше и больше...

- Вообще я против таких обобщений. Вот вы же прочитали, и Вам было интересно. И Валера считал также. Нельзя говорить - деградация народа. Мы это не понимаем. Потому что Валера всегда цитировал Андрея Планова: «Без меня народ не полный». Народ - это я. Вы, все. Поезжайте в наши деревни и посмотрите, как говорят тётя Вера, тётя Маня, да у них прекрасная русская речь, талантливая, яркая. Народ русский безумно талантлив. Именно народ хранит язык, и он очень талантлив. Мы не придумаем никогда ту шутку, которую скажут жители деревни Урдово, какая она будет блестящая по языку, какая яркая. Они говорят так ярко! Язык развивается и хранится там. Валера очень много слов подчерпнул из Урдово. Убожество это начальнички. Вот это убожество как они говорят. Народ - это и наши бабки в Урдово, и Вы, и я, и Валерка. Мы - народ. А они считают, что народ это где-то. Что они - элита, люди не образованные, за счёт того, что они материально богаты, поэтому они элита. А народ язык сохранит, и всё будет нормально. И я, и Валера очень оптимистичны. Надо самому не деградировать, и чтобы у нас была речь лучше, стараться. Чем позже к вечеру, тем она лучше. Думайте о себе! Я читаю, я стараюсь читать трудные книги. Кажется, трудно читается - а я вот прочту. И так каждый сам для себя. Ну вот эта деградация вот где-то там кто-то... Надо самому!

- Давайте тогда перейдём к следующему вопросу. Форма обращений. Вопрос актуальный, не исключаю вероятности того, что его уже задавали вам. На сегодняшний день у нас нет формы обращений, я к вам обращаюсь «Елена», и если я бы так позволил себе обратиться к вам лет 30 назад, меня бы посчитали за ненормального. Как же по имени и без отчества?!

- Мы усвоили европейское обращение.

- Пропало «товарищ», потому что оно несёт в себе дух коммунизма, «милостивые государе и государыни» - не поймут, не знаю - приживётся ли, загадывать не буду, но на сегодняшний день выглядит как издевка. И, конечно же, обращение на «ты», у нас любят: «ты» мне должен, чего «ты» делаешь. Что творится с обращениями? Куда мы идём? И Золоторотов в романе также над этим раздумывает...
- Золоторотов ни в коей мере не является альтер-эго Валеры, совершенно.

- Как и автор не является.

- $\quad$ Да, всё таки все персонажи - выдуманные, и Валера раздал себя на всех. Например, его родословная у Отца Мартирия: шахтёрский поселок, шахтёры. Это Валерина родословная. И он подарил её Отцу Мартирию, гиганту. Гиганту-монаху. Каждый писатель раздаёт себя всем персонажам. Какие-то свои черты или какие-то события своей жизни. Писатель в общем-то вещь неоднозначная, многогранная. Чем больше писатель тем он многогранней, и на большее количество персонажей его хватит, самых разных. В каждом человек много чего понамешано. И тем драматург хорош, что он может говорить разными голосами, потому что все они живут в нём. Насчёт обращений - ну это волнует Золоторотова, вот такой русский интеллигент.

- Иногда это неудобно, хочется всё же уважить человека старше себя не только по возрасту, но и по статусу. Называть просто по имени, на мой взгляд, недостаточно уважительно. Хотелось бы обращаться иначе. Как тогда поступать в этом случае?

- Никак, мы перешли на европейскую форму. Отчества, конечно, не уйдут, совсем пожилых людей естественно будут называть по отчеству в России... Хотя человеку перейти на отчество очень трудно.

- Это вес, на мой взгляд.

- $\quad$ Когда пошла работать во ВГИК мне было 44, и когда меня называли Еленой Теодоровной, я очень смеялась по этому поводу. Но как-то прижилось там, когда я ушла из ВГИКа, - конечно, нет! Моя мама, например, всю жизнь проработала, 32 года во ВГИКе, и вела мастерские, её называли Полина Ивановна. С тех пор она для всех Полина, ей так надоело это «Полина Ивановна». Для женщины это ещё и очень возрастное... Надо смириться с тем, что тебя зовут по имени, отчеству.

- $\quad$ Я понимаю, что уважение будет определяться в первую очередь не обращением, а интонационно.

- Конечно-конечно. Да. Да и вообще отчество это тоже некий барьер. Я не скажу малознакомому человеку - просто Лена. Чем и ужасны кстати наши начальники - это своим «ты». «Ты» подразумевает ответное «ты», когда вы приходите к кому-то старше по званию и этот человек говорит вам «ты» - это хамство, потому что «ты» предполагает ответное «ты». Или мы на «ты», или мы на «вы». У воспитанных людей. Либо же, когда человек говорит Вам «ты», а Вы отвечаете 
ему на «Вы» - это предполагает очень большую разницу в возрасте. То есть он вам «ты», вы мне «вы», это значит - он признал свой возраст. Всё остальное хамство. Вот у нас Никита Михалков всем тыкает, вот считает себя барином и всем тыкает, это выглядит отвратительно.

- $\quad$ Но это же унижает его в первую очередь.

- Конечно, но очень многие переняли эту его манеру и это мерзко. Правильные обращения, всё-таки, выстраивают некую дистанцию и отношения, и это прекрасно.

- Роман - 1696 страниц, цифра из Википедии. Огромный объём по сегодняшним меркам, хоть я и прочитал в раз, на одном дыхании. Есть ли невошешдшее? Исключённое? Много ли и почему?

- Да. Валера очень переживал, что такой размер. Неужели больше «Война и мир»? Ему было неловко. И, конечно, он сокращал. Четвёртую часть, очень сильно сократил вторую часть, документов было больше. Ему очень хотелось, чтобы человек читал с неослабевающим интересом, чтобы было увлекательно, чтобы мысли, которые он хотел перенести, какие-то вещи, которые он хотел понять и понять для себя, и он ни секунды не забывал, что всё-таки литература должна быть увлекательной. И он всех спрашивал, где ослабевает внимание, что выкинуть, что? И вот во второй части, моя мама читала, она сказала, во второй части можно что-то сократить. Там много он сократил. Потому что размер был просто огромный.

- $\quad$ При этом при всём, при том, что осталось, - документы читаются очень легко и интересно.

- Ну они двигают сюжет, развивают его. Но он сокращал, сокращал...

- Роман благоискательский. это главное в общем. Он же многослойный.

- Ознакомился с многими отзывами, как критиков, так и простых читателей. Многие сходятся во мнении, что роман стоит добавить в школьную программу.

- Я думаю в школе рановато его читать, такой большой роман.

- $\quad$ Перенесут на программу высших школ - почему бы нет?

- Конечно хотелось бы. Потому что Валера жизнью заплатил за этот роман. Я помню читала Солженицына «Как телёнок с дубом бодался», и там были такие слова, мне запомнились: «Что же это за страна такая, что же это за романы пишут в России, за которые люди платят жизнью?». Это написал Солженицын. Они мне запомнились, эти слова. Валера действительно заплатил за этот роман жизнью, поэтому мне бы очень хотелось, конечно, чтобы он остался в русской литературе, конечно мне бы хотелось чтобы его перевели.

- Экранизация? Вы представляете??

- Ни в коем случае. Там в этом романе я вижу, как минимум, 10 фильмов. Там очень много материала. Подобно «Мастеру и Маргарите». Ни в коем случае не хотела, чтобы это был сериал. Я отношусь к сериалам очень... Я считаю, что люди, работающие на сериалах, как режиссёры, так и сценаристы, - теряют квалификацию. Потому что то, чему нас учили во ВГИКе, нас учили драматургии, это уникальная профессия. Получается что драматургов всегда очень мало. Это умение рассказать всю жизнь, или большую очень важную историю - тогда было 70-75 страниц сценария, на очень маленьком количестве страниц. Драматург, театральный драматург, в двух действиях рассказывает целую жизнь. Целые истории, эпопеи. Очень мало людей обладают этим драматургическим даром донесения. Очень много прекрасных писателей не умеют писать ни сценарии, ни пьесы. Это особый дар, уложить большую историю на очень ограниченное пространство и заставить, чтобы через диалог развивалось действие или картинки кино складывались в историю. И нас так учили, я считаю это правильным. Не зря мастерские были по 10 человек, и из каждой выходил один от силы. Потому что это очень редкий дар. А то, что происходит с сериалами, этот дар уничтожают, ты маленькую историю растягиваешь. Есть и хорошие сериалы, кинороманы. Американцы делаю хорошие сериалы. Но это совершенно другая природа, природа людей, которые смотрят эти сериалы, тоже другая. Всё же это уклад домохозяек, ну представьте себе нормального мужчину, со своей работой, с талантом, представьте, что он садится каждый вечер и смотрит сериалы. Я, например, такого мужчину не могу себе представить. Ну, только если дедушка, которому ещё и нечего делать. Что делает твой папа? Муж? Он так увлечён сериалом таким-то. Это странно. Пока я жива - на сериалы я ни за что не отдам. Фильм - смотря кто режиссёр. Конечно можно сделать прекрасный фильм про Золоторотова, про Мартирия и Мардария.

- Можно сделать множество фильмов одного произведения.

- Да-да, как «Мастер и Маргарита», всё разобрано по частям. Наверное, если был бы хороший режиссёр, то я была бы рада, конечно.

- А если разбить «Свечку» на отдельные книги. По частям. 
- Была идея издать не двухтомником, а папочкой с книжечками, каждая на свою историю. Обложку, кстати, придумал Валера, написано, конечно, художник такой-то, но это Валерина обложка. У нас всегда висела на стене, пока он работал, над книжкой «Святой Христофан». Если бы пришёл хороший режиссёр, я не знаю, кто это, если кто-то бы предложил инсценировку прекрасную, почему нет?! Конечно хо- чется чтобы его и перевели, но ведь он писался 12 лет, а значит и переводиться будет года четыре, поэтому неизвестно, когда это будет. А пока только «Большая книга» и второе место.

- $\quad$ С чем, конечно же, я Вас поздравляю и желаю дальнейшей волны признания. А место... время всё расставит на свои места. Онегина тоже читали в своё время сотни, а может пару сотен людей.

\section{Список литературы:}

1. Залотуха В.А. Великий поход за освобождение Индии: роман. М.: Эксмо, 2006. 288 с.

2. Залотуха В.А. Макаров: повести. М.: Текст, 2000. 315 с.

3. Залотуха В.А. Отец мой шахтёр. Избранное. М.: Время, 2016. 864 с.

4. Залотуха В.А. Свечка: в 2 т. Т. 1: роман в 4 частях с приложениями и эпилогом. М.: Время, 2015. 832 с.

5. Залотуха В.А. Свечка: в 2 т. Т. 2: роман в 4 частях с приложениями и эпилогом. М.: Время, 2015. 864 с.

\section{References (transliterated):}

1. Zalotukha V.A. Velikii pokhod za osvobozhdenie Indii: roman. M.: Eksmo, 2006. $288 \mathrm{~s}$.

2. Zalotukha V.A. Makarov: povesti. M.: Tekst, 2000. $315 \mathrm{~s}$.

3. Zalotukha V.A. Otets moi shakhter. Izbrannoe. M.: Vremya, 2016. $864 \mathrm{s.}$

4. Zalotukha V.A. Svechka: v 2 t. T. 1: roman v 4 chastyakh s prilozheniyami i epilogom. M.: Vremya, 2015. $832 \mathrm{~s}$.

5. Zalotukha V.A. Svechka: v 2 t. T. 2: roman v 4 chastyakh s prilozheniyami i epilogom. M.: Vremya, 2015. 864 s. 